\title{
COMMON GROUND: Archaeological Practice and Local Communities in Southeastern Turkey
}

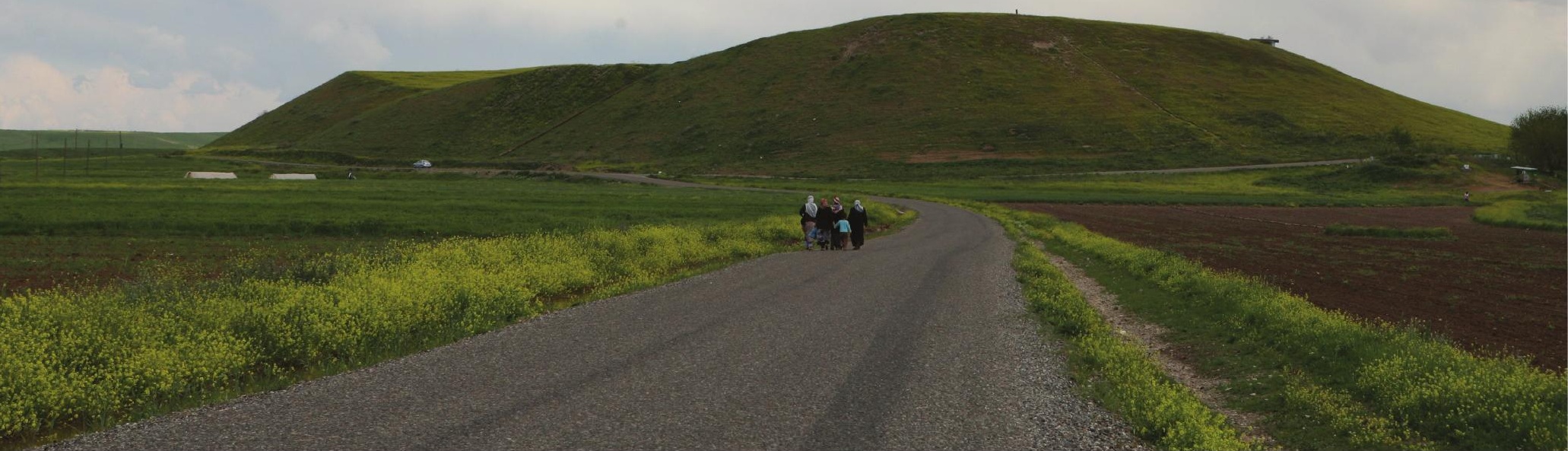

Figure 1. Eastward view of the mound of Ziyaret Tepe. Photograph by H. McDonald.

\section{Melissa Rosenzweig and Laurent Dissard}

7 here has been a growing disquiet among archaeologists over the dynamics of inequality historically embedded in the archaeological project (Baird 2011; Dawdy 2009; Hamilakis and Duke 2007). For those doing research abroad, anxieties about knowledge claims and civic responsibilities are compounded by the complications of working under the specter of colonialism and the reality of present-day socio-political conditions. In response, community archaeologists have worked toward establishing multi-vocal, non-exclusive, nonhierarchical forms of scientific practice (Derry and Malloy 2003; Little and Shackle 2007; Merriman 2004; Watson and Waterton 2008). Community archaeology emphasizes the creation of permeable boundaries that allow non-archaeologists access to excavation sites and activities for the promotion of archaeological research and education (Atalay 2007; Breglia 2007; Kuhns 2008; Marshall 2002). We would like to argue that in order for excavations to remain inclusive and viable, community archaeology must further provide for the desires of non-archaeologists to pursue non-archaeological concerns in and around sites. Community archaeology is, first and foremost, archaeology conducted within communities. Any collaborative program that seeks to destabilize hierarchies embedded in archaeological practice, we posit, must first wrestle with the tensions that emanate from running scientific projects (with their own attendant power structures) in non-scientific, communal spaces. In our observations and experiences of fieldwork at Ziyaret Tepe, we have found that archaeological discourse alone cannot achieve the multilateral dialogue sought through collaborative practice. Instead we discovered, through the intervention of a funeral procession, that ceding archaeological priority over to local affairs not only preserves the integrity of the archaeological project, but also expands the value of sites as locations with scientific, historic, and contemporary meaning.

\section{An Unexpected Human Burial}

Since 1997, a multidisciplinary and international team of archaeologists has been working at the site of Ziyaret Tepe in southeastern Turkey (fig. 2) to uncover its Late Assyrian settlement (ca. 900-600 B.C.E.), as well as other historical remains from the late third millennium to the Ottoman period (MacGinnis and Matney 2009). Excavations have taken place every summer for the past 15 years, as part of a larger salvage project preceding the construction of the Ilisu hydroelectric dam on the Tigris River, which will flood areas northeast of the mound. Consequently, the summer arrival of the archaeologists constitutes a regular, seasonal event for the people of Tepe, the host community.

Tepe is small town (or belde) of around 8,000 people located on the southern bank of the Tigris River in the modern province 
of Diyarbakır (fig. 3). Tepe's community is largely comprised of underprivileged, Kurdish-speaking residents; but four large, wealthier families have lived in the region for several generations now ${ }^{1}$. The well-established families generate income from cash cropping their lands (with wheat, cotton, lentils, corn, e.g.) and employ Tepe's other residents as seasonal farm laborers. The archaeologists also hire many of the local men who tend these fields as manual laborers for the excavation.

Early during a recent excavation season, a respected female member of one of these powerful families in Tepe passed away. This family decided that the matriarch's

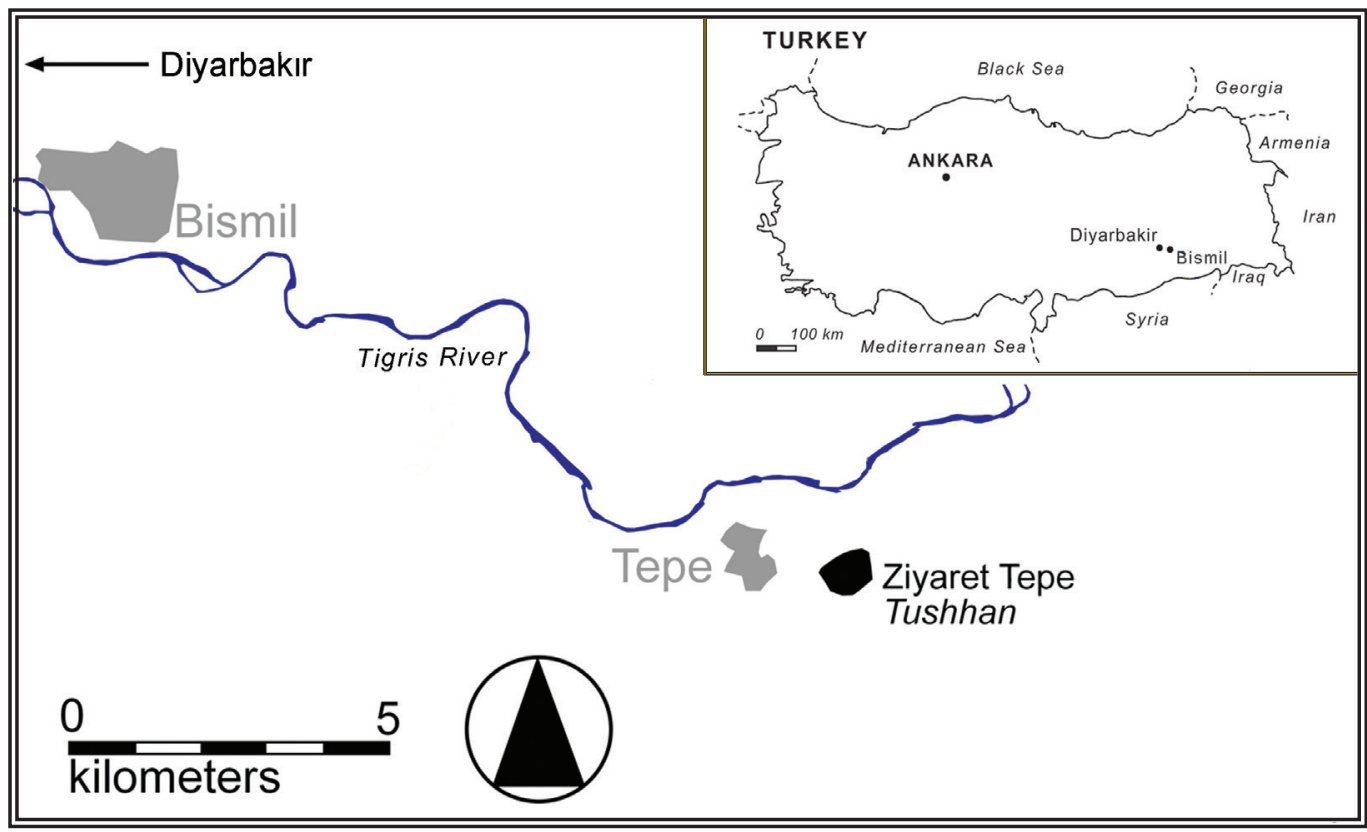

Figure 2. Map of the village of Tepe and the archaeological site of Ziyaret Tepe, adapted with permission from the Ziyaret Tepe Archaeological Expedition. Inset map of Turkey adapted from Ronayne 2005: figure 1:7. final resting place would be among her relatives' graves on the cemetery atop Ziyaret Tepe (fig. 4). Although Tepe contains several available burial places, the top of the mound carries special significance as a graveyard for this particular family. In fact, the site itself, Ziyaret Tepe, obtains its name from the existence of these present-day tombs, the word ziyaret referring both to the act of pilgrimage to local sacred sites and to the religious sites themselves. More specifically, the mound attracts visitors to a türbe, or small shrine, built around the tomb of Sheikh Muhammad, an honored religious leader who lived and died in Tepe several decades ago. For these reasons, the people of Tepe value the mound of Ziyaret Tepe as a sacred burial site and a destination for memorial and prayer. Generations before archaeologists arrived to perform their own scientific pilgrimage, local people have been coming to Ziyaret

Tepe to visit the cemetery, inter friends and family, and remember loved ones.

It is extremely rare for an interment to take place on the mound, much less in the midst of a field season, and it was unclear among all parties involved how to proceed. The wishes of the deceased's family brought the excavations to a temporary halt so that various stakeholders in the management of the mound could gather to discuss the situation. Present were the deceased's senior family members, Ziyaret Tepe's project director, the state's Ministry of Culture and Tourism representative, as well as the Diyarbakır Museum's director, the local jandarma captain, and the town's imam. Each attendee represents a node in the nexus of relationships that personifies the community within which the Ziyaret Tepe project operates day in and day out. But prior

Figure 3. View of the village of Tepe from the mound of Ziyaret Tepe. Photograph by A. Wodzińska.

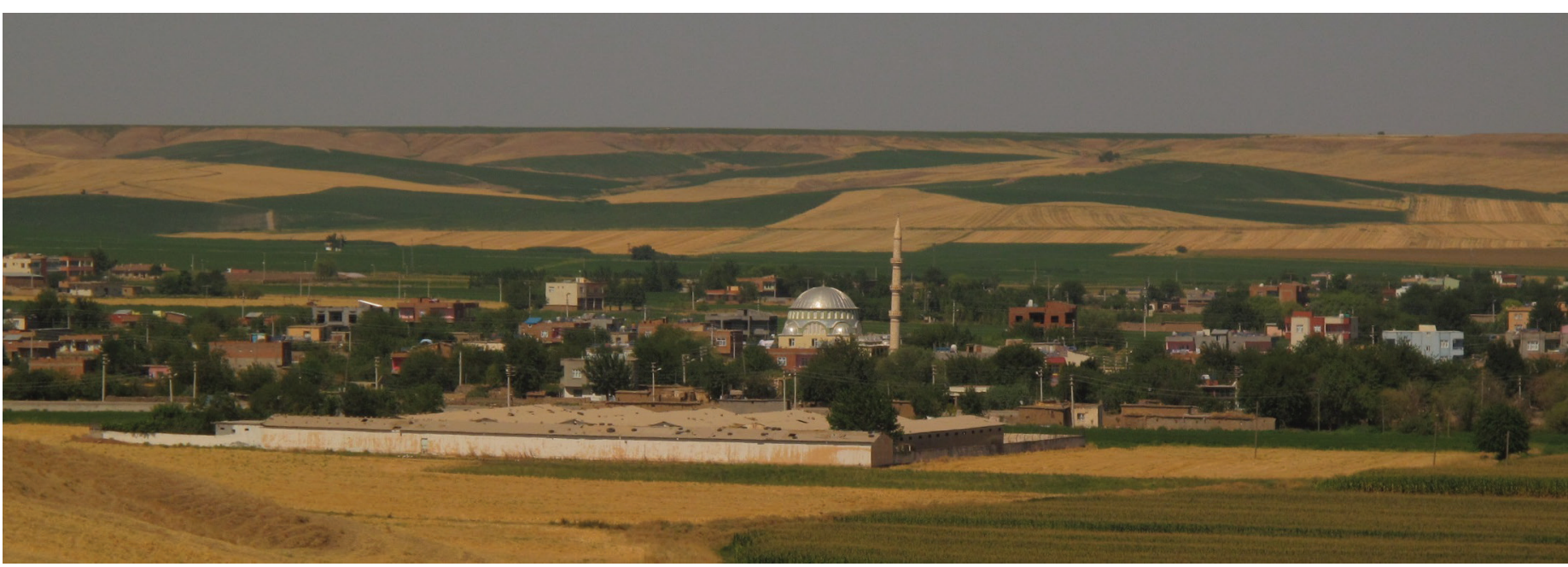


to this event, this strategic assembly of vested representatives had never actually come together as one to discuss the site and its administration. At this rare but significant convention, two critical outcomes unfolded for the actualization of community archaeology that we advocate: (1) Ziyaret Tepe's community context emerged from the interplay of history, politics, and culture that each representative brought to bear on the maintenance of the mound, and (2) the participants acknowledged, reaffirmed, and preserved the site's meaningfulness as both an archaeological and sacred place. greatly influenced the social and economic trajectory of each town. On the one hand, as a district center (or belediye), Bismil profited from the business and amenities generated by state investment, including new roads, schools, and banks, as well as a post office and hospital. On the other hand, Tepe's denizens would not witness major infrastructural development, such as electricity, until the 1980s, when the migration of people caught in the conflict between the Turkish army and the Kurdish Workers' Party (PKK) dramatically increased Tepe's population. It is within this political history, as representatives of both a histori-

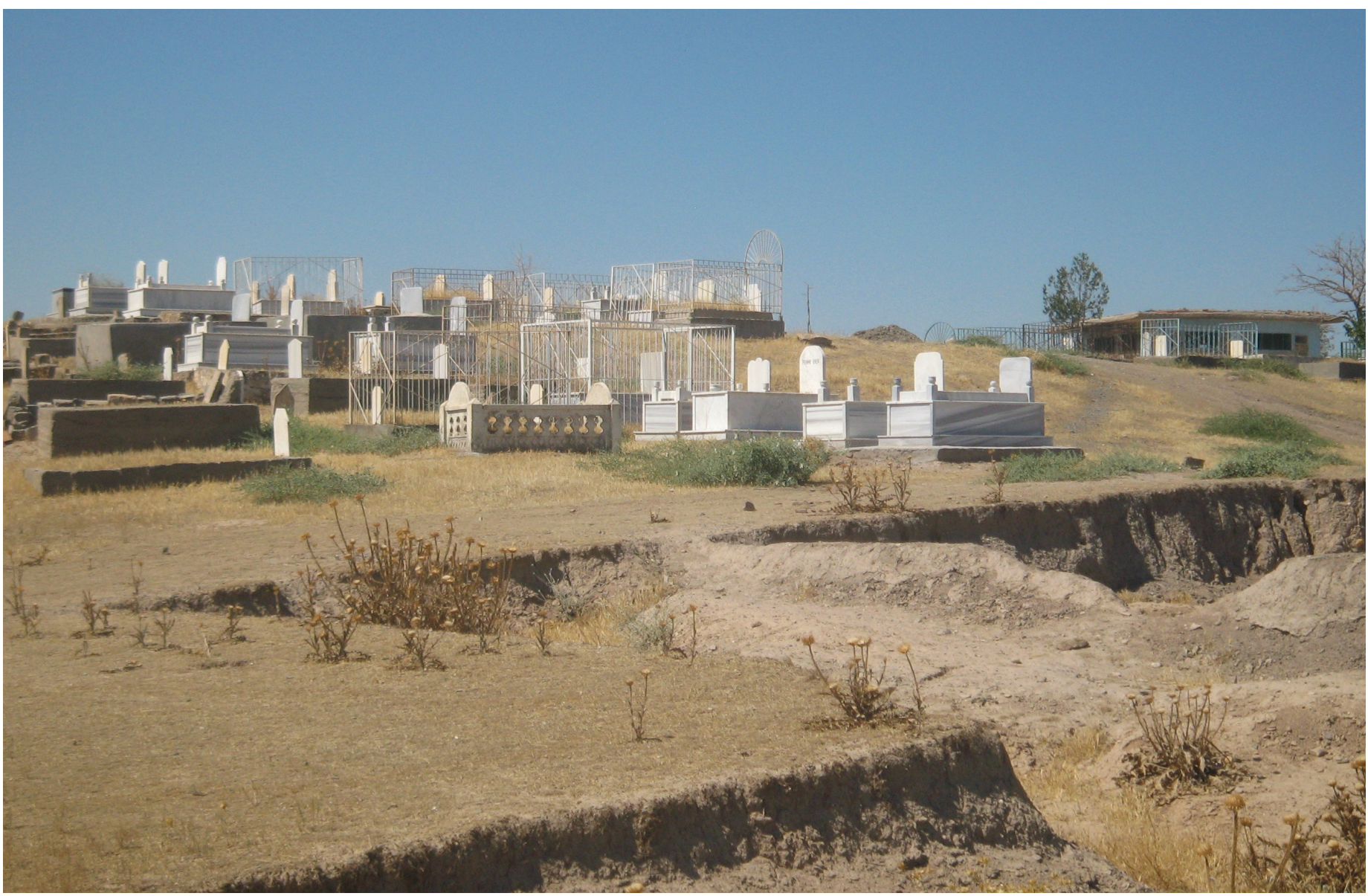

Figure 4. The cemetery located atop the Ziyaret Tepe mound, adjacent to the excavation trenches. Photograph by M. Rosenzweig.

\section{Ziyaret Tepe's Community Context}

Tepe's history informs the ways in which its residents interact with and understand the Ziyaret Tepe project and its management. Before the foundation of the Turkish Republic in 1923, the Kurdish-speaking residents of Tepe enjoyed relative prosperity and independence vis-à-vis the central authorities in and out of the region. In the 1930s, however, the government in Ankara, with an eye towards strengthening Turkish national identity, intensified the process of restructuring its southeastern provinces (Üngör 2011). Officials designated the city of Diyarbakır, $65 \mathrm{~km}$ west of Tepe, as the capital of a province with the same name, and declared the Turkish-speaking village of Bismil head of a provincial district that included Tepe (see fig. 2). This political decision cally Kurdish village and a state-run municipality, that the family of the deceased approached the other authority figures gathered to discuss the burial. Powerful by local standards, the Kurdish relatives of the deceased nonetheless found themselves requesting permission from Turkish officials and foreign visitors to perform one of the most sacred of their culture's traditions. Thus, the politics of the situation tempered the family's inclusion in the decision-making process, and from the outcome of the meeting the mourners would gauge the other participants' regard for local, Kurdish concerns.

The state representative and museum director, both sensitive to the local politics of the matter, found themselves weighing the petition of the local people against the possibility of breaking 
protocol by allowing private individuals to conduct a burial on state land. Designated by the state as an archaeological site, the mound could no longer legally accommodate new burials (fig. 5). These officials thus had to navigate the expectations of both the Ministry of Culture and Tourism, to assess the loss of cultural heritage, and of a local family and their religious leader (imam), to honor the wishes of the bereaved and respect Muslim burial customs. Moreover, whatever verdict the group reached would be enforced by the local military police (jandarma) charged with security in rural areas of the country, as well as set a precedent for future activities on the mound. Despite all of the particularities of this specific context, the state representative and museum director faced a common cultural heritage problem: negotiating between the protection of the past and the preservation of present, local customs.

Into this already complicated foray entered the archaeologists who come to Ziyaret Tepe with their own set of objectives and obligations; namely, to conduct scientific research of academic value by the rules set forth by the Ministry of Culture and Tourism. Tasked with the power to explore the mound of Ziyaret Tepe (fig. 6), they depend upon the Ministry for access to the site and upon the regional museum for a great

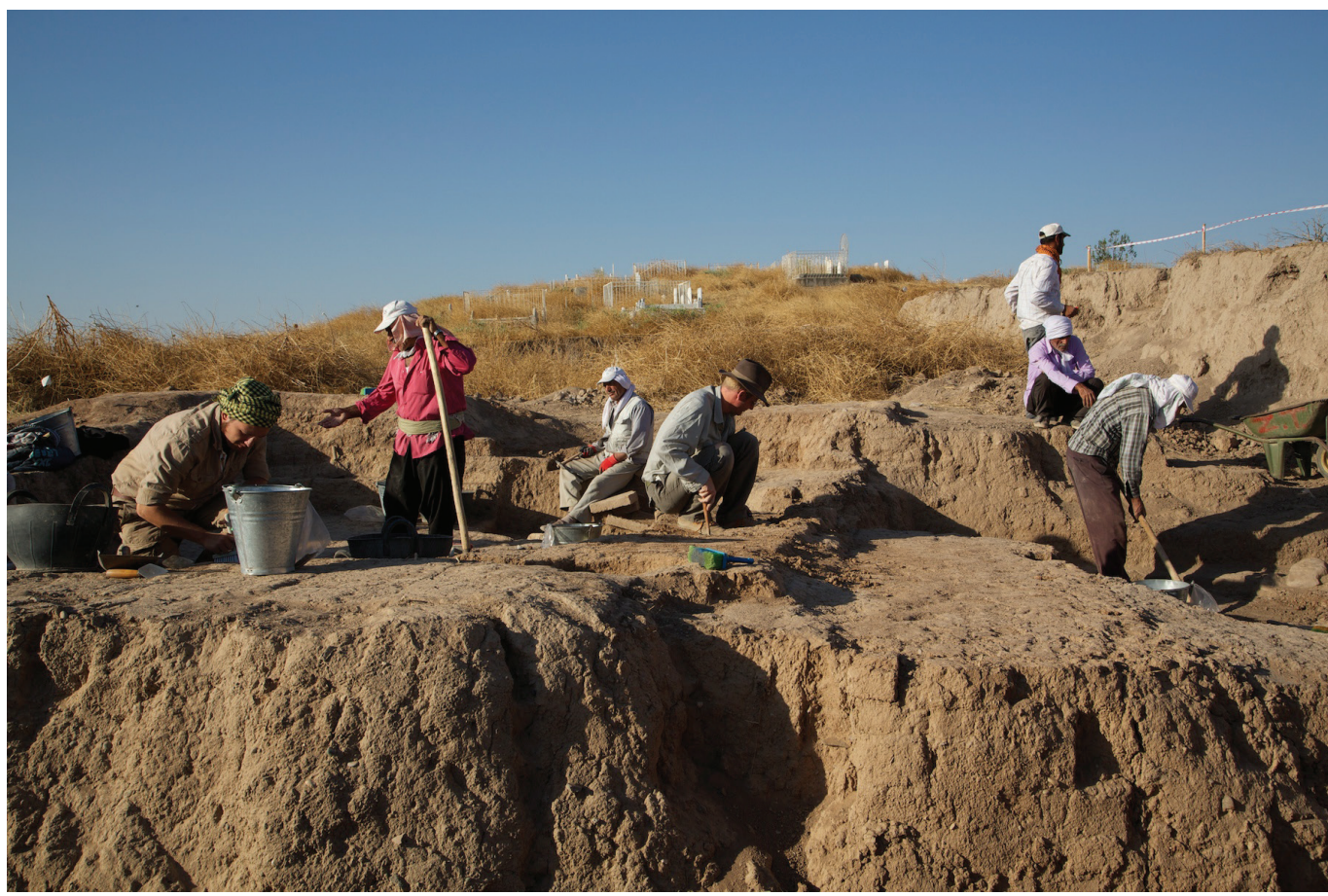

Figure 5 (above). Excavation on the high mound, with the cemetery in the background.

Figure 6 (below). Excavation in the lower town of Ziyaret Tepe, with the high mound visible in the background. Photographs by lan J. Cohn.

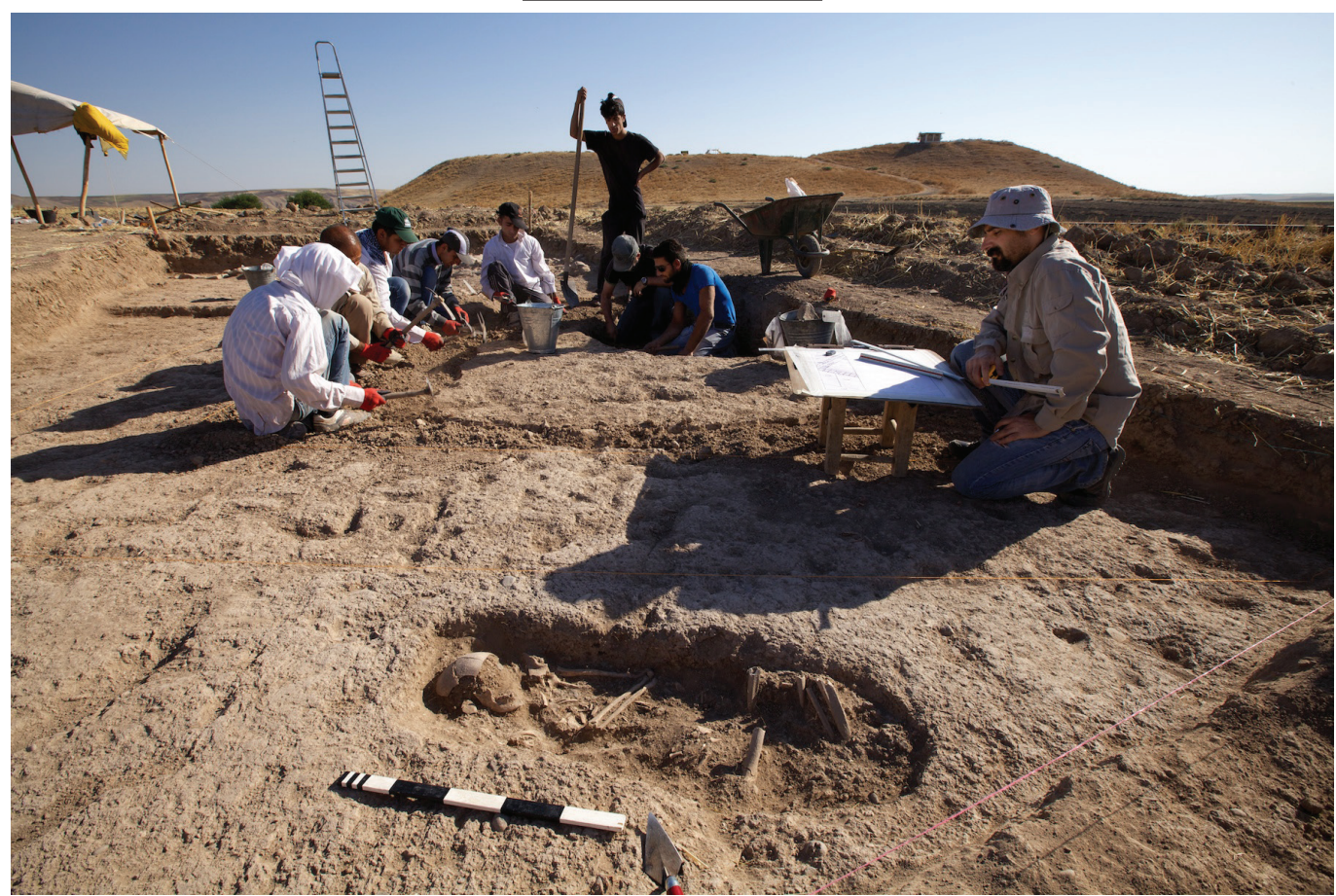

deal of support and resources,

including storage facilities and artifact curation. The overriding authority of the Ministry and the project's reliance upon the museum attenuated the director's ability to alter archaeological practice and easily accommodate the unexpected funeral. The meeting consequently exposed a latent limitation of all archaeological work conducted under state license: despite the unique concerns of individuals, organizations, or institutions involved in the research, the site is ultimately the property of the state and subject to its legal discretion. In other words, the scientific space of excavation is always political in its existence and, more often than not, contested in its design.

The archaeologists' desire to observe the protocols of the Ministry challenged their equal commitment to maintaining good relations with the residents of Tepe, upon whom they rely for labor, logistics, and hospitality. When the project first began, a lack of irrigation technology limited summer agriculture. Since 
arriving in Tepe, the project has become a major seasonal employer for the village (fig. 7), providing a much-needed source of revenue during this particularly slow season. Modern water management systems have since become widespread in Tepe's fields, making summer cropping jobs more available; but the expectation of work on the archaeological project remains and the excavation regularly employs around sixty men, some of whom have been with the project for many years.

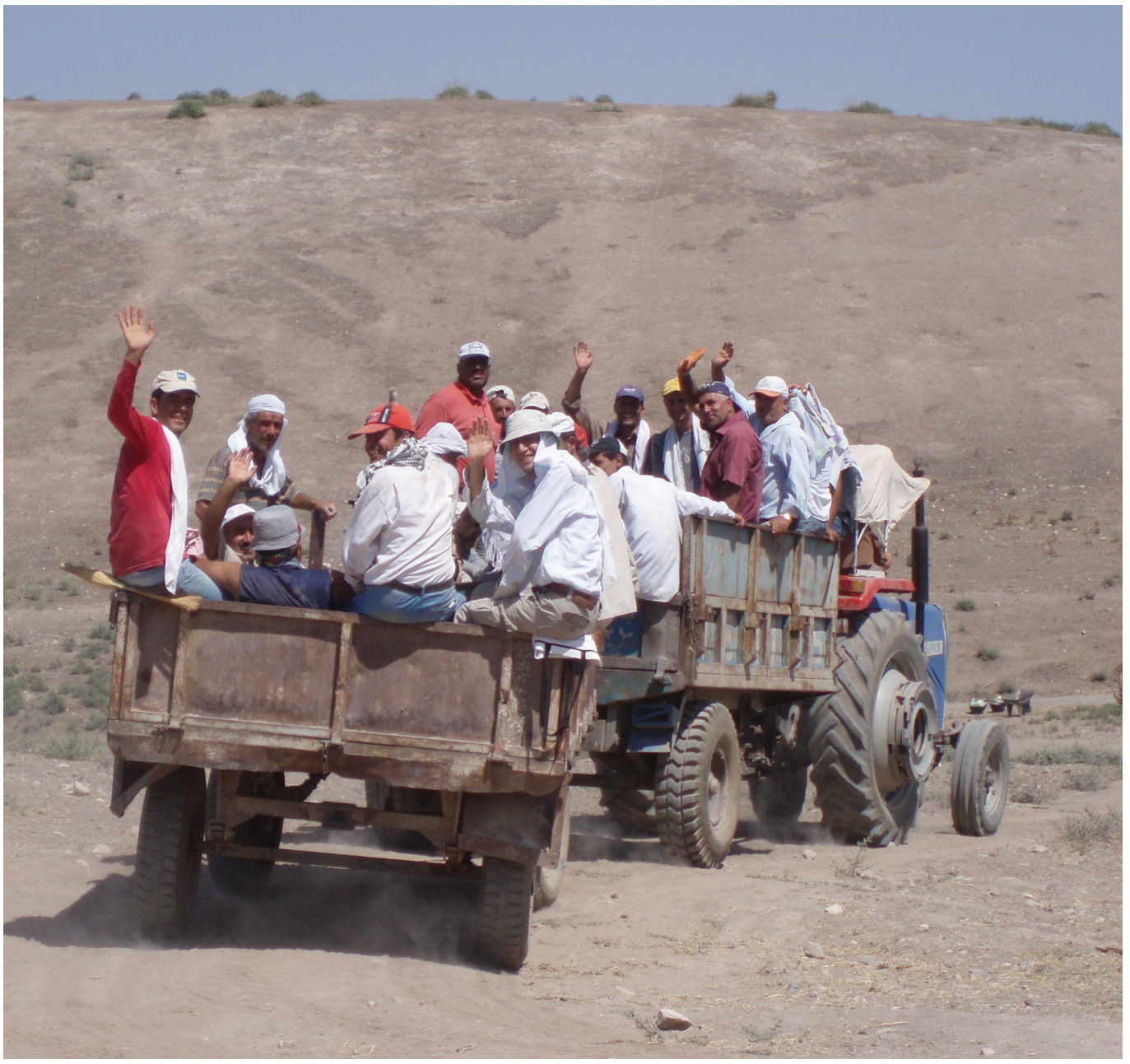

Figure 7. Villagers hired as laborers headed to the mound of Ziyaret Tepe. Photograph by M. Rosenzweig.

the funeral would determine the current state of community relations between the archaeologists and the locals.

\section{Common Ground: Coming Together to Respect the Past and the Present on the Mound}

In the end, after consultation with the Ministry, the funeral did take place upon the mound and over one hundred people attended (fig. 8). The archaeologists considered the interment of little consequence to the overall excavation; the $2 \times 2 \mathrm{~m}$ grave constituted less than 0.00001 percent of the site's surface. The ground ceded in this decision, trivial in its physical properties, yielded enormous significance in its discursive implications. The archaeological director worked with state officials to conceive of the mound as something other than a state-owned property or a scientific space for excavation. In addition, the foreign team and the Turkish authorities made room for non-official, local practices that "treat[ed] material objects of the past as integral to the routines of daily life and the fabric of social space" among living communities (Hamilakis 2008, 278). In that move, they indeed carried out the aims of community archaeology and achieved common ground. The decision, small in its scale, but large in its scope, paid deference to the religious and cultural claims of the mourners, who sought the right to continue their burial tradition; and it accorded meaningful recog-

Just as the archaeologists are grateful for the Ministry's and Museum's support, but forever mindful of these departments' authority, so too are the residents of Tepe appreciative for the summer work, but cognizant as well of the archaeologists' ability to wield a disproportionate amount of power and resources during their short, annual stays. The archaeologists have the fiscal means to procure a great deal of labor and supplies; the social capital to transcend traditional religious, gender, and kinship boundaries; and the political clout to negotiate with, and sometimes overrule, local leadership. At this moment of decisionmaking, for the people of Tepe, community archaeology meant just how much consideration the community would receive at the hands of archaeologists. Therefore, the pronouncement on nition to the people of Tepe, who sought proof that the archaeologists and attendant officials cared for the community that lived and worked beside them, even when their concerns did not reflect those of the archaeologists. Their voices mattered, not just in the performance and interpretation of archaeological work (cf. Hodder 2002, 176-7), but in the performance and interpretation of their daily, non-archaeological lives. The local leaders and community members, likewise, made compromises that secured the legitimacy of the archaeological project. The funeral attendees respected the boundaries of the open trenches, and all parties agreed to limit future interments to the existing empty plots of the cemetery, where archaeological work is already precluded, so as to prevent further expansion of the burial ground. 


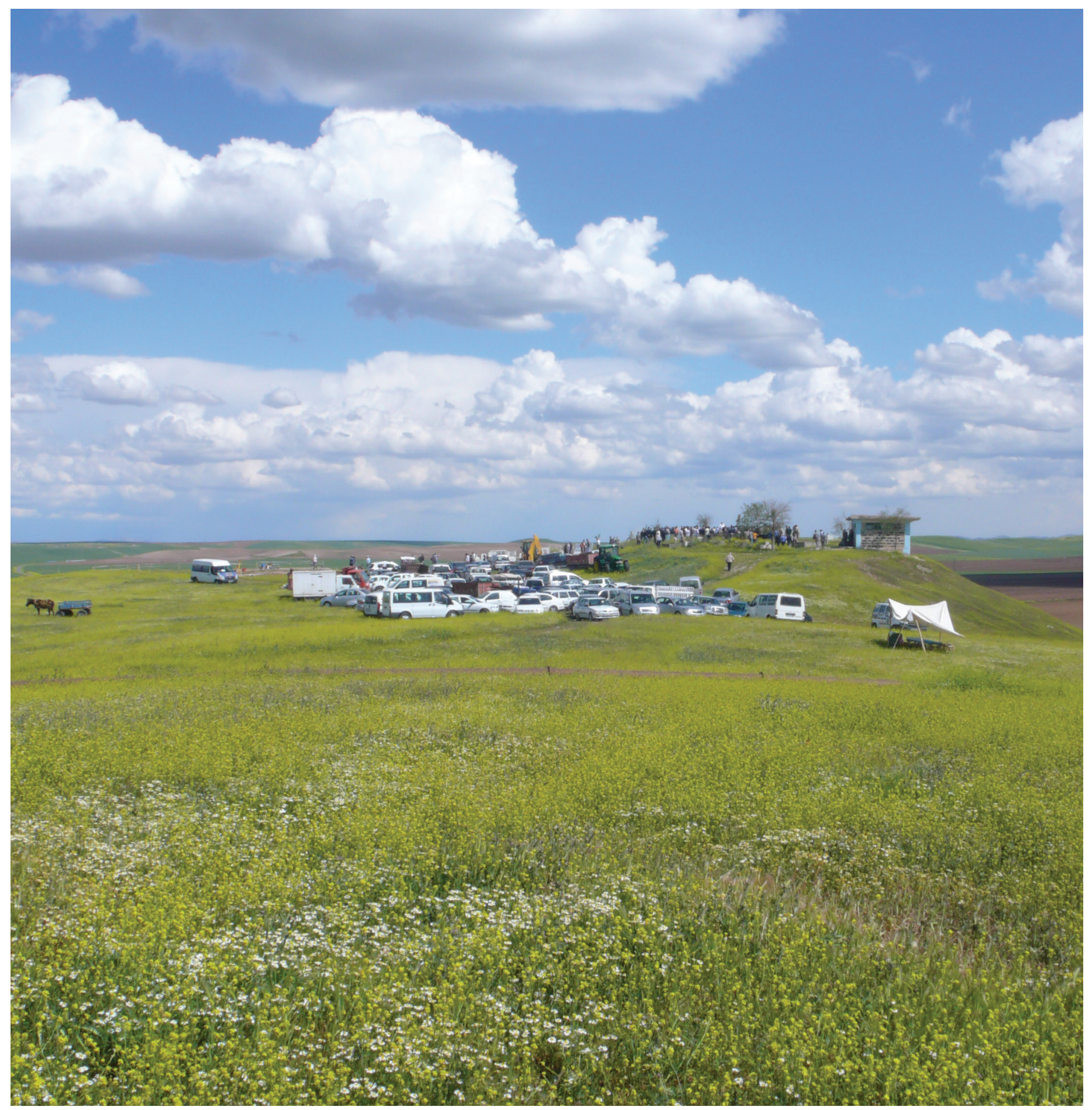

Figure 8. The funeral taking place on the high mound of Ziyaret Tepe. Photograph by M. W. Monroe.

The collaboration achieved good will on all sides, even though the group that gathered to discuss the funeral had to confront competing claims and conflicting commitments. We would like to emphasize that the concession to non-archaeological pursuits did not undermine the overall scientific project, and in fact garnered a greater respect for the excavation and its team members. Nor was the achievement in community relations one-sided. The archaeologists, too, gained from the experience. By valuing the local community's understandings of and interactions with $\mathrm{Zi}-$ yaret Tepe, the archaeologists found perspective on their own work in the field. They confronted, and overcame, the difficulty of pursuing fieldwork as if the excavation site is a bounded, scientific space, free of outside stimuli or non-archaeological controversies. They discovered that acknowledging the mound as something other than an archaeological space increased, rather than decreased, the meaningfulness of the place, and successfully crossed the past/present divide that inevitably accompanies all fieldwork. Finally, as an approach to balancing the power 
structures of archaeological practice, the unexpected funeral gave Ziyaret Tepe's archaeologists an opportunity to assess the status quo, question their own authority, and contextualize the authority of those around them. Consideration of the locals' non-archaeological perceptions of the mound made these crosscommunity connections and insights possible.

\section{Note}

${ }^{i}$ Even though they share some similarities with the large, traditional Kurdish tribes (aşiret) of the region, as described by van Bruinessen (2002), the families of Tepe are not as sizable and would never refer to themselves as tribes.

\section{References}

Atalay, S. 2007. Global Application of Indigenous Archaeology: Community Based Participatory Research in Turkey. Archaeologies: Journal of the World Archaeological Congress 3(3): 249-70.

Baird, J. A. 2011. Photographing Dura-Europos, 1928-1937: An Archaeology of the Archive. American Journal of Archaeology 115:427-46.

Breglia, L. C. 2007. Engaging Local Communities in Archaeology: Observations from a Maya Site in Yucatán, México. Pp. 89-99 in Past Meets Present: Archaeologists Partnering with Museum Curators, teachers, and Community Groups, eds. J. H. Jameson, Jr. and S. Baugher. New York: Springer.

Dawdy, S. 2009. Millennial archaeology. Locating the discipline in the age of insecurity. Archaeological Dialogues 16(2):131-42.

Derry, L. and M. Malloy. 2003. Archaeologists and Local Communities. Washington, D.C.: Society for American Archaeology.
Hamilakis, Y. 2008. Decolonizing Greek archaeology: indigenous archaeologies, modernist archaeology and the post-colonial critique. Pp. 273-84 in A Singular Antiquity: Archaeology and Hellenic Identity in Twentieth-Century Greece, eds. D. Damaskos and D. Plantzos. Athens: Benaki Museum.

Hamilakis, Y. and P. Duke. 2007. Archaeology and Capitalism: From Ethics to Politics. Walnut Creek, CA: Left Coast Press.

Hodder, I. 2002. Ethics and Archaeology: The Attempt at Çatalhöyük. Near Eastern Archaeology 65(3):174-81.

Kuhns, E. 2008. A participatory action research approach to collaborative archaeology. Dublin: World Archaeological Congress.

Little, B. J. and P. A. Shackel. 2007. Archaeology as a Tool of Civic Engagement. Lanham, MD: AltaMira Press.

MacGinnis, J. and T. Matney. 2009. Ziyaret Tepe: Digging the Frontier of the Assyrian Empire. Current World Archaeology 37:30-40.

Marshall, Y. 2002. What Is Community Archaeology? World Archaeology 34(2):211-19.

Merriman, N. 2004. Public Archaeology. London: Routledge.

Ronayne, M. 2005. The Cultural and Environmental Impact of Large Dams in Southeast Turkey. London: National University of Ireland, Galway and Kurdish Human Rights Project.

Üngör, U. Ü. 2011. The Making of Modern Turkey: Nation and State in Eastern Anatolia 1913-1950. Oxford: Oxford University.

van Bruinessen, M. 2002. Kurds, states and tribes. Pp. 165-83 in Tribes and Power: Nationalism and Ethnicity in the Middle East, eds. F. A. Jabar and H. Dawod. London: Saqi.

Watson, S. and E. Waterton. 2008. Community Engagement: Collaboration or Contestation. Dublin: World Archaeological Congress.

\section{ABOUT THE AUTHORS}

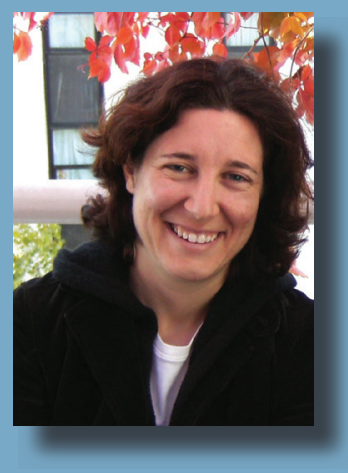

Melissa Rosenzweig is a Ph.D. candidate in Anthropology at the University of Chicago. She serves as the archaeobotanical specialist for the Ziyaret Tepe excavations in Turkey, as well as for the Tel Akko Total Archaeology project and field school in Akko (Acre), Israel. Her forthcoming dissertation investigates the intersections of agriculture and empire at Ziyaret Tepe under Late Assyrian rule. In addition to advocating community archaeology practices, her research interests include the investigation of imperial dynamics in the ancient Near East, the study of past human-environment interactions, and the application of political ecology to archaeological theory and methods.

Laurent Dissard is an Andrew W. Mellon Postdoctoral Fellow at the University of Pennsylvania Penn Humanities Forum. He is currently working on a book manuscript entitled Submerged Stories: Salvage Excavations and Cultural Erasure in Eastern Turkey, on the history of rescue archaeology before the construction of large dams on the Euphrates River. He also regularly writes about the politics of the past in Turkey on his website Past \& Present.

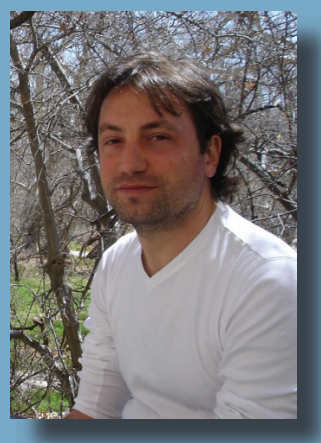

